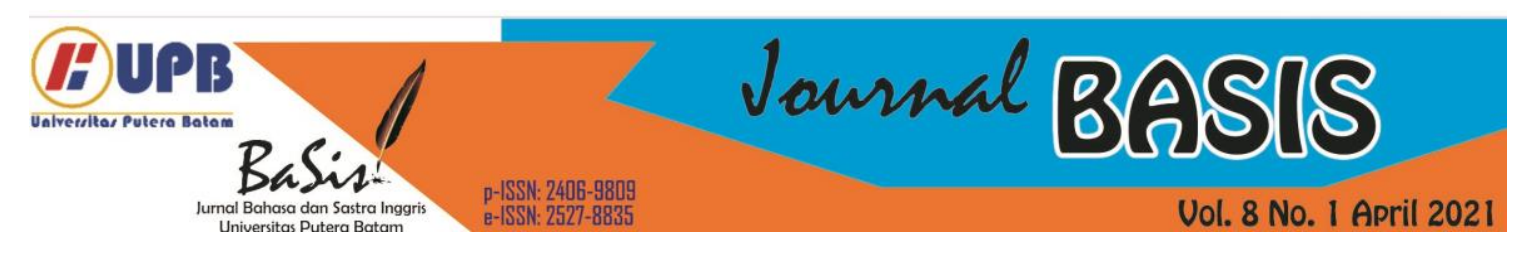

\title{
KINDS OF TRANSLATION METHOD USED BY THE STUDENTS' IN TRANSLATING DESCRIPTIVE TEXT FROM ENGLISH TO INDONESIAN
}

\author{
Ester Riska Sianturi ${ }^{1}$ \\ Universitas Prima Indonesia, Medan, Indonesia \\ sianturiesterriska@gmail.com \\ Elen Magdalena Marpaung ${ }^{2}$ \\ Universitas Prima Indonesia, Medan, Indonesia \\ elenmagdalena23@gmail.com \\ Susi R. Sipahutar ${ }^{3}$ \\ Universitas Prima Indonesia, Medan, Indonesia \\ susisipahutar02@gmail.com \\ Kartina Rahmadhani Rambe ${ }^{4}$ \\ Universitas Prima Indonesia, Medan, Indonesia \\ kartinarambe@gmail.com
}

\begin{abstract}
This research aims to analyze the kinds of translation method used by the eight grade students at SMP Yayasan Perguruan Karya Bhakti. The method of this research was descriptive qualitative. The sample of this research was the eight grade students at SMP Yayasan Karya Bhakti. There are two instruments of this research, namely the first test is about translating the English text into Bahasa and the second test is interview test, there are 10 questions in interview test. In translation analysis process, the researchers used theory of translation method based on Newmark theory. The findings of this research showed that there are only four method used by the students in translating the text. They are Literal Translation, Faithful Translation, Word-for-Word Translation and Free Translation. It can be seen from the table that the most dominat method used by 10 students was literal translation and faithful translation method. The second dominant was word-for-word translation and free translation method. Here, the students used more than one method to tranlate the descriptive text.
\end{abstract}

Keywords: Analysis, Descriptive Text, Translation Methods.

\section{INTRODUCTION}

English is a worldwide dialect used to communicate throughout the world. As a result, proficiency in English is needed by everyone who needs information. For this reason, most people have to learn English. English as a foreign language in this country must be studied by students in schools and English is one of the main subjects in schools. English teachers sometimes find students difficult in the process of learning English because some students think that learning English is very difficult so that students cannot translate every word, sentence, or paragraph in a text.

Translation is an effort to divert messages from one language to another language. According to (Newmark: 1988), translation is as "A craft consisting of attempts to write statements and replace messages in one 
language with the same statements and messages in another language".

According to Siregar (2015) states that translation is essential in the development of the national language by increasing its capacity as a medium of communication. Translation is very useful, especially for people who can't speak and understand foreign languages.

To form a translation method, translation experts provide several translation methods as described by Peter Newmark (1988: 45-47), namely word of word translation, literal translation, faithful translation, free translation, semantic translation, idiomatic translation, adaptation translation, communicative translation.

Based on the description above, in the translation process, students experienced many difficulties translating several texts. Some of the difficulties faced by students are students having difficulties understanding the meaning of text and students having difficulties understanding translating new vocabulary. To understand the text content, students must be able to interpret each sentence or every piece of content from several types of text content in English. The analyst focuses on one type of text content, namely descriptive text.

Descriptive text is a text that describes a person, animal, and also an object. Be it in form, quantity, or nature. According to (Kane 2000: 352) that descriptive text is a sense experience - how it looks, sounds, tastes. Generally around visual encounters, but depictions also bargain with other kinds of recognition.

According to (Corbett 1983), descriptive text can be in the form of an expressive interpretive composition that aims to communicate the sound, taste, and aroma of an object or object.

Based on the previous explanation, the researcher believes that students also find it difficult when translating descriptive texts. Therefore, to overcome this problem, of course, some tricks or treatments are used by the teacher in class when teaching translation.

The researchers take some previous study that analyzed about translation. The object of previous research was argumentative text, descriptive text, and narrative text.

Based on the explanation above, the researcher is curious to analyze students' methods in translating English descriptive text into Indonesian. Through analyzing the students' translation methods, people come to find out what difficulties are experienced by students and what strategies can be used by students, especially at the Junior High School level. In this study, the analyst focused on the student's retention method in interpreting descriptive text content from English to Indonesian which was made by the SMP Yayasan Perguruan Karya Bhakti.

\section{LITERATURE REVIEW}

\subsection{Translation}

\section{A. Definition of Translation}

Budianto and Fardhani (2010, P.3) said that translation is a natural translation that flows as if original written in the target language form. The grammar and vocabulary contained in this translation are not strange and not awkward. Therefore, in translating a person must ensure that he or she has received some considerations in making multiple adjustments to the target language context in sequence in order to produce a good and natural translation.

Djuwariah (2011: 21) states that translation is the result of translation 
exercises, as well as sending discussions from the source language (SL) to the target language (TL).

According to (Wills in Cholilludin: 2005) translation can be a step that directs the content of the source language text to the target language text content which is ideally proportional and requires expansion of sentence structure, style, semantics, and understanding of the content of the pragmatic text by the translator of the original text. Based on the definition above, the researchers conclude that, translation is process to translate a language (source language) into another language (target language).

\subsection{The Kinds of Translation Method}

Before a translator performs a translation, a translator must decide who or the purpose for which the translation will be used. Therefore, translators are often based on a design person's request or a needs check. In honing translation, the translator must choose one method that suits whom and for what purpose the translation is used.

According to Newmark (1988:45) there are eight types of translation method; word for word translation, free translation, literal translation, faithful translation, semantic translation, adaptation translation, idiomatic translation, and communicative translation. Here are the eight translation methods by Newmark:

\section{Word For Word Translation}

Translation word for word in this way, the translator translates the content of the source language into the content of the target language by looking at the word reference. As a result, they make word choices that are not basic and the translation sounds unattractive and unnatural to the reader, because the word structure in the translated sentence cannot be distinguished from the word order in the original sentence.

\section{Free Translation}

Free translation is usually not tied to proportional sentence searches, but similarities tend to occur at the sentence level. The translator must be able to push messages in the source language at the paragraph level or discourse as a whole and then exchange and express them in the target language. This is difficult to do, especially for untrained translators. Where there are free translations, such translations are generally limited to the level of expression, clause or sentence. Informal expressions and proverbs are often translated unconditionally.

\section{Literal Translation}

Literal translation is found between word to word translation and free translation. A proper literal translation may begin with something like word-toword translation, but then the translator adjusts the word order in the target sentence. This kind of usually relates if the sentence structure of the source language is different from the structure of the target language.

\section{Faithful Translation}

Faithful translation will attempt to produce the correct contextual meaning of the original usage structure within the limits of the target grammar. This shows that in a faithful translation, the translator must be able to decipher the meaning of the source language to communicate the aims of the researchers.

\section{Semantic Translation}

Semantic translation is translating less critical social words into a third or useful term which is socially impartial but not parables. Semantic translation is more adaptable than faithful translation because in this translation there is a style of appreciating and compromising the meaning of the content from the source language as long as it is in 


\section{context.}

\section{Adaption Translation}

Adaptation translation is the 'freest' form of translation. It is basically used for dramatization (comedy and poetry, subjects, characters, plots, short stories, stories, etc.) and is usually protected, the culture of the source language is transformed into the culture of the target language and the contents of the text are rewritten.

\section{Idiomatic Translation}

Idiomatic translation is an interpretation that produces a 'message' from the original, but tends to change the subtleties of meaning by choosing colloquial language and idioms that are usually displayed in the original.

\section{Communicative Translation}

A communicative translation is a translation that tries to create relevant and precise meaning from the original in such a way that the substance and content of the language can be effectively recognized and captured by the reader.

\subsection{The Process of Translation}

The process of translation consists of three steps (Nida \& Taber, 1982:33), as follows:

\section{Analysis}

The translator has to analyze the kind of the text before translating the source language. Moreover, a text that will be translated should be comprehended by translator or ask another person who is considered more skillful and knowledgeable to help in that subject. For instance, when the translator found medical issue in the translated text and the translator has no clue to the medical terms, as a result translator will be confused and create disorganized translation. That is the reason why an understanding of a text is becoming essential part of translating, all above can be obtained by analysis.

\section{Transfer}

Transfer is becoming the next stage of process translation after analysis. Transfer is not an easy work, because each language has a different meaning and concept. Therefore, the closest equivalent words, phrase, clause and sentence from the source language to the target language should be founded by the translator.

\section{Restructuring}

The latest stage is restructuring. This is the modification stage, when a message is transfer by the translator with a word equivalent the translator needs to adjust the sentences for the better by separating the term from the term from the source language without having any strange meaning. From explanation above, it can be inferred that a translator should have knowledge and skill about source language and target language. So, the translator can achieve the equivalent meaning from source language to target language.

\subsection{Descriptive Text}

\section{A. Definition of Descriptive Text}

Hartono (2003) state that descriptive text is writing, which tells about how the person, creature or object is being described or depicted.

According to Nugroho (2012) in Oktarina (2014:2), descriptive text is a kind of texts that describes the figure of someone based on their characteristic or acts. We can also describe something and some place based on their characteristic. In descriptive text, one of language features that are always used is simple present tense.

Based on the definition above, the researchers conclude that descriptive text is describe about person, animal, place and things that always use simple present tense. 


\section{B. Generic Structure of Descriptive Text}

When writing descriptive text, there are a number of common structures to ensure that our composition is correct. The steps are:

1. Identification: contains introducing the individual, creature, place or object to be described.

2. Description: contains the depiction of something such as a creature, object, place, or individual by describing the characteristics, shape, color, or anything related to what the author describes.

C. Purpose of Descriptive Text

a. To describe a special individual, object, or place.

b. To describe a specific individual, object or place.

\section{RESEARCH METHOD}

This research approach uses descriptive qualitative. Ary (2010: 29), says that qualitative research can become a phenomenon by focusing on the overall picture rather than breaking it down into variables. The goal could be an all-encompassing overview and depth of understanding rather than examining numerical data. The design in this research is a case study. A case study is a type of ethnographic investigation that centers on a single entity, such as a person, a group, an organization, or a program.

Qualitative research is inquire about that extraordinary to get it the wonder experienced by research subjects such as behavior, perception, motivation, action. In a holistic manner, and by meaning of descriptions in the form of words and language, in a special natural context and by utilizing various natural methods.

The subject of the research focused on the eighth Grade of SMP Yayasan Perguruan Karya Bhakti. The researchers choose one class which is used as a simple sample of the study. The class is eighth grade which consists of ten students.

The source of data is descriptive text about animal text taken from English in Focus for Grade VIII Junior High School book on the KTSP basis. The data of this research will be presented in written form, in which it will describe the results of the analysis related to the kinds of translation method used in the descriptive text.

The researchers are the keys instrument. The researchers use three types of test. The first test is about translating the English text into Bahasa. And the second test is interview test, there are 10 questions in interview test. The researchers also use documentation types in this research.

The researchers will do some procedures to collect the data. The procedures are:

1) The researchers will share a paper of a descriptive text to the students.

2) The researchers will guide the students to read the text first.

3) The researchers will instruct the students to translate the text.

4) The researchers limit the time.

5) After the students have finished, the researchers will collect the students' paper.

In the technique of data analysis, the researchers used qualitative data. By using this technique, researchers collect data, organize data, and present data. Qualitative data analysis is a type of research without using statistical calculations or procedures.

According to Miles and Huberman in Sugiyono (2015: 338) say that the method of data analysis called interactive model. The following are the analysis techniques used in this research: 


\section{Data Collection}

Data collection may be a very intuitive and handle. The data set is a collection of data in the form of writing. Whereas the data collected between these steps are continuous in order to understand all the desired data in the other data checking steps. In this research, the analysis collected data from students through interview and test.

\section{Data Reduction}

Data reduction is a method of sorting and selecting relevant data or not important data for an investigation. Therefore, data reduction can be a preparation for reordering and transforming the data from the structured information frame through changing, sharing, and summarizing the data.

\section{Data Display}

The next technique is data display. Data display organizes compresses and collects data. Qualitative data forms include any type of measurement, chart, graph, or system. This kind of data display serves to display data that can be obtained, compressed, and monitored. Researchers showed the transcripts of the translation methods students used in the translation process.

\section{Data Verification}

Data verification or conclusion displays conclusions from the data that has been collected by the study. The researchers interpreted the data display analysis. The results show that through data verification the researchers have

\begin{tabular}{llll}
\hline No. & Student's Name & \multicolumn{2}{l}{ The Method Used by Students } \\
\cline { 3 - 4 } 1. & Vinky $\left(1^{\text {st }}\right.$ Student $)$ & Paragraph 1 & Paragraph 2 \\
2. & Hermon Zeit & Literal Translation & Faithful Translation \\
3. & $\left(2^{\text {nd }}\right.$ Student $)$ & Word for Word & Faithful Translation \\
4. & Ainun $\left(3^{\text {td }}\right.$ Student $)$ & Translation & \\
5. & $\begin{array}{l}\text { Sahidunasa } \\
\left(5^{\text {th }} \text { Student }\right)\end{array}$ & Literal Translation & Faithful Translation \\
6. & $\begin{array}{l}\text { Rama Danu } \\
\left(6^{\text {th }} \text { Student }\right)\end{array}$ & Free Translation & Free Translation \\
\hline
\end{tabular}

the possibility to make conclusions and confirm the translation methods used by the students in the translation process.

\section{RESULT AND DISCUSSION \\ 4.1 Results}

In this research, researchers conducted research and completed the data by collecting students as participants in this research. Data collection was carried out at SMP Yayasan Perguruan Karya Bakti which was taken from grade VIII. In data collection, the researchers conducted two instruments, namely analyzing descriptive text and answering interviews about the difficulties experienced by students when translating a text.

In data collection, the researchers provided translated text for the students to translate and several interviews for students to answer. There were 10 grade VIII students who participated in this research. From the translation methods analyzed, the researchers found some of the methods most often used by students in translating text and the researchers also found some students' answers about the difficulties they experienced in translating a text. Here, the researchers will present data about the kinds of translation methods used by the students based on Newmark's (1988) theory and present students' answers to interviews about the difficulties they experience in translating a text: 


\begin{tabular}{clll}
\hline 7. & $\begin{array}{l}\text { Neisyahira } \\
\text { br. Siahaan }\left(7^{\text {th }} \text { Student }\right)\end{array}$ & Literal Translation & Faithful Translation \\
8. & $\begin{array}{l}\text { Liza Alfa Nesha } \\
\left(8^{\text {th }} \text { Student }\right)\end{array}$ & $\begin{array}{l}\text { Word for Word } \\
\text { Translation }\end{array}$ & $\begin{array}{l}\text { Word for Word } \\
\text { Translation }\end{array}$ \\
9. & $\begin{array}{l}\text { Nadya Syalsabila } \\
\left(9^{\text {th }} \text { Student }\right)\end{array}$ & $\begin{array}{l}\text { Literal Translation } \\
\text { Nanda Vergesola } \\
\left(10^{\text {th }} \text { Student }\right)\end{array}$ & Free Translation \\
10. & Literal Translation & Faithful Translation \\
\hline
\end{tabular}

\title{
4.2 Discussions
}

\subsubsection{The Kinds of Translation Used by The Students}

\section{The Kinds of Translation Method Used by The Students}

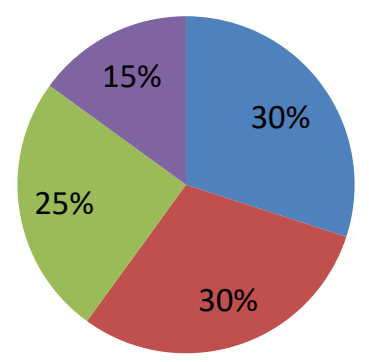

\author{
- Literal Translation \\ - Faithful Translation \\ Word for Word \\ Translation \\ Free Translation
}

\section{Analysis:}

\subsubsection{Literal Translation (30\%)}

Literal translation is found between word to word translation and free translation. A proper literal translation may begin with something like word-toword translation, but then the translator adjusts the word order in the target sentence. This kind of usually relates if the sentence structure of the source language is different from the structure of the target language.

As the example it found that the student used this kind of translation as follow:

\section{Vinky (Paragraph 1)}

SL: "She comes from a dense forest on the island of Kalimantan"

TL: "Dia berasal dari hutan lebat di pulau Kalimantan"

In this sentence, the student uses the Literal Translation method, because the word in the lexical is not translated independently, but she tries to translate the text as closely as the text in the target language. For example in the sentence "a dense forest on the island of Kalimantan" the student translated the sentence without paying attention to word for word, but she translates according to his understanding.

\section{Nazwa (Paragraph 1)}

SL: "She comes from a dense forest on the island of Kalimantan"

TL: "Dia berasal dari hutan lebat di pulau Kalimantan"

In this sentence, the student uses the Literal Translation method, because the word in the lexical is not translated independently, but she tries to translate the text as closely as the text in the target language. For example in the sentence "a dense forest on the island of Kalimantan" the student translated the sentence without paying attention to 
word for word, but she translates according to his understanding.

\section{Sahidunasa (Paragraph 1)}

SL: "She comes from a dense forest on the island of Kalimantan"

TL: "Dia berasal dari hutan lebat di pulau Kalimantan"

In this sentence, the student uses the Literal Translation method, because the word in the lexical is not translated independently, but she tries to translate the text as closely as the text in the target language. For example in the sentence "a dense forest on the island of Kalimantan" the student translated the sentence without paying attention to word for word, but she translates according to his understanding.

\section{Neisyahira br. Siahaan (Paragraph 1)}

SL: "She comes from a dense forest on the island of Kalimantan"

TL: "Dia berasal dari hutan lebat di pulau Kalimantan"

In this sentence, the student uses the Literal Translation method, because the word in the lexical is not translated independently, but she tries to translate the text as closely as the text in the target language. For example in the sentence "a dense forest on the island of Kalimantan" the student translated the sentence without paying attention to word for word, but she translates according to his understanding.

\section{Nadya Syalsabila (Paragraph 1)}

SL: "She comes from a dense forest on the island of Kalimantan"

TL: "Dia berasal dari hutan lebat di pulau Kalimantan"

In this sentence, the student uses the Literal Translation method, because the word in the lexical is not translated independently, but she tries to translate the text as closely as the text in the target language. For example in the sentence "a dense forest on the island of Kalimantan" the student translated the sentence without paying attention to word for word, but she translates according to his understanding.

\section{Nanda Vergesola (Paragraph 1)}

SL: "She comes from a dense forest on the island of Kalimantan"

TL: "Dia berasal dari hutan lebat di pulau Kalimantan"

In this sentence, the student uses the Literal Translation method, because the word in the lexical is not translated independently, but she tries to translate the text as closely as the text in the target language. For example in the sentence "a dense forest on the island of Kalimantan" the student translated the sentence without paying attention to word for word, but she translates according to his understanding.

\subsubsection{Faithful Translation (30\%)}

Faithful translation will attempt to produce the correct contextual meaning of the original usage structure within the limits of the target grammar. This shows that in a faithful translation, the translator must be able to decipher the meaning of the source language to communicate the aims of the researchers.

As the example it found that the student used this kind of translation as follow:

\section{Vinky (Paragraph 2)}

SL: "She has physical features similar to a human"

TL: "Dia memiliki ciri fisik yang mirip dengan manusia"

In this sentence, student uses the Faithful Translation method, because the student tries to produce contextual meanings that are precise from the original within the constraints of the target grammar. For example, in the word "physical features similar" the student translates the meaning according to its true meaning. 


\section{Hermon Zeit (Paragraph 2)}

SL: "She has physical features similar to a human"

TL: "Dia memiliki ciri fisik yang mirip dengan manusia"

In this sentence, student uses the Faithful Translation method, because the student tries to produce contextual meanings that are precise from the original within the constraints of the target grammar. For example, in the word "physical features similar" the student translates the meaning according to its true meaning.

\section{Nazwa (Paragraph 2)}

SL: "She has physical features similar to a human"

TL: "Dia memiliki ciri fisik yang mirip dengan manusia"

In this sentence, student uses the Faithful Translation method, because the student tries to produce contextual meanings that are precise from the original within the constraints of the target grammar. For example, in the word "physical features similar" the student translates the meaning according to its true meaning.

\section{Sahidunasa (Paragraph 2)}

SL: "She has physical features similar to a human"

TL: "Dia memiliki ciri fisik yang mirip dengan manusia"

In this sentence, student uses the Faithful Translation method, because the student tries to produce contextual meanings that are precise from the original within the constraints of the target grammar. For example, in the word "physical features similar" the student translates the meaning according to its true meaning.
5. Neisyahira
br.
Siahaan

SL: "She has physical features similar to a human"

TL: "Dia memiliki ciri fisik yang mirip dengan manusia"

In this sentence, student uses the Faithful Translation method, because the student tries to produce contextual meanings that are precise from the original within the constraints of the target grammar. For example, in the word "physical features similar" the student translates the meaning according to its true meaning.

6. Nanda Vergesola (Paragraph 2)

SL: "She has physical features similar to a human"

TL: "Dia memiliki ciri fisik yang mirip dengan manusia"

In this sentence, student uses the Faithful Translation method, because the student tries to produce contextual meanings that are precise from the original within the constraints of the target grammar. For example, in the word "physical features similar" the student translates the meaning according to its true meaning.

\subsubsection{Word for Word Translation} $(25 \%)$

Translation word for word in this way, the translator translates the content of the source language into the content of the target language by looking at the word reference. As a result, they make word choices that are not basic and the translation sounds unattractive and unnatural to the reader, because the word structure in the translated sentence cannot be distinguished from the word order in the original sentence.

As the example it found that the student used this kind of translation as follow:

\section{Hermon Zeit (Paragraph 1)}

SL: "There is an orangutan in the Bandung Zoo" 
TL: "Ada seekor orangutan di Kebun Binatang Bandung"

In this sentence, student uses the Word for Word Translation method, because the words are translated individually with the most general meaning, usually the text translated uses this method out of context. For example, in the sentence "an orangutan" the student translates the meaning "an orangutan".

2. Rama Danu (Paragraph 1)

SL: "There is an orangutan in the Bandung Zoo"

TL: "Ada orangutan di dalam kebun binatang Bandung"

In this sentence, the student uses translate using the Word for Word Translation method, because student translates that by following the meaning of words with the most common meanings. For example, the sentence "in the Bandung Zoo" translates to mean "didalam kebun binatang".

3. Rama Danu (Paragraph 2)

SL: "Bongo is almost as big as a human"

TL: "Bongo sebesar manusia"

In this sentence, the students translate using the Word for Word Translation method, because students translate it by following the word for word meaning with the most common meaning. For example, the sentence "as big as a human" translates to mean "sebesar manusia".

4. Liza Alfa Nesha (Paragraph 1)

SL: "There is an orangutan in the Bandung Zoo"

TL: "Ada orangutan di dalam kebun binatang Bandung"

In this sentence, the student uses translate using the Word for Word Translation method, because student translates that by following the meaning of words with the most common meanings. For example, the sentence "in the Bandung Zoo" translates to mean "didalam kebun binatang".

5. Liza Alfa Nesha (Paragraph 2)

SL: "Bongo is almost as big as a human"

TL: "Bongo sebesar manusia"

In this sentence, the students translate using the Word for Word Translation method, because students translate it by following the word for word meaning with the most common meaning. For example, the sentence "as big as a human" translates to mean "sebesar manusia".

\subsubsection{Free Translation (15\%)}

Free translation is usually not tied to proportional sentence searches, but similarities tend to occur at the sentence level. The translator must be able to push messages in the source language at the paragraph level or discourse as a whole and then exchange and express them in the target language. This is difficult to do, especially for untrained translators. Where there are free translations, such translations are generally limited to the level of expression, clause or sentence. Informal expressions and proverbs are often translated unconditionally.

As the example it found that student used this kind of translation as follow:

\section{Ainun (Paragraph 1)}

SL: "There is an orangutan in the Bandung Zoo"

TL: "Ada orangutan di sebuah kebun binatang di Bandung)

In this sentence, the student uses the Free Translation method, because the student translates it without the procedure and does not pay attention to the original form. For example, in the sentence "in the 
Bandung Zoo" is translated to "di sebuah kebun binatang di Bandung" the student translates it by adding a few words to complete the sentence in the target language according to their understanding.

\section{Ainun (Paragraph 2)}

SL: "Bongo is almost as big as a human"

TL: "Bongo menyerupai orang yang bertubuh besar"

In this sentence, the student uses the Free Translation method, because the student translates it without the procedure and does not pay attention to the original form. For example, in the sentence "almost as big as a human" is translated to "menyerupai orang yang bertubuh besar". Here the student translates by adding a few words to complete the sentences in the target language according to their understanding.

\section{Nadya Syalsabila (Paragraph 2)}

SL: "She has physical features similar to a human"

TL: "Dia memiliki ciri fisik yang sama dengan manusia"

In this sentence, the student uses the Free Translation method, because the student translate the meaning of the source language into the target language using the most appropriate word without paying attention to the original form. For example, in the word "Similar" the translator defines it as the word "sama", but the most suitable meaning in the sentence is that the word "Similar" is translated into the word "mirip".

\subsubsection{How Those Kinds of Translation Used by The Students}

\subsubsection{Literal Translation}

Students use this method because the grammar construction source is converted to the closest grammar target, so students try to translate the text as close as possible to the text in the target language, so that the reader can understand the results of the translation.

\subsubsection{Faithful Translation}

Students use this method because students try to produce contextual meanings that are right from the original within the constraints of the grammar target, so that students must be able to translate the meaning of the source language to convey the researcher's intent.

\subsubsection{Word for Word Translation}

Students use this method because students translate it by following the meaning word for word with the most common meaning, so students often choose the wrong meaning of the word and the translation sounds strange to the reader.

\subsubsection{Free Translation}

Students use this method because it is not tied to the search for the equivalent of the sentence but the search for the equivalent tends to occur at the level of paragraph discourse, so that students translate it without procedures and do not pay attention to its original form.

\subsubsection{The Difficulties Facing in Translating from Interview}

In this research, interviews are very important to use to determine students difficulties in translating a text from English to Indonesian. The participants in this research were 10 students and the researchers choose 10 students to be interviewed. There were 10 questions presented by the researchers. The results of interviews with students, researchers concluded that the problem that many students 
face in learning English is translating a text.

Currently researchers ask the students what difficulties that the students find to translate the text. According to Nazwa as a student said that the difficulty she experienced when translating a text when she met or got new words that had not been learned.

Another answer was from

Hermon Zeit as a student, he said that the difficulty he experienced in translating a text when he encountered a subject or object that had never been studied, so that it made him confused in translating the text.

\section{CONCLUSION}

Based on the above findings, the research problems posed by researchers in this study have been understood. The researchers can conclude that:

1. The eight types of translation methods based on Newmark's (1988) theory, only four types of translation methods are used by students in translating descriptive text which are literal translation, faithful translation, word for word translation, and free translation, while other translation methods are not used by the students, which are adaptation translation, semantic translation, idiomatic translation, and communicative translation. From the four methods they used, the dominant methods students used are literal translation and faithful translation.

2. The students used literal translation, faithful translation, word for word translation, and free translation based on their knowledge and comprehension in translating English text into Bahasa Indonesia.

3. The difficulty faced by students in translating a text is their lack of mastery of vocabulary so that in translating activities are still lacking.

\section{REFERENCES}

Amalya, D. R., Syam, U. K., Augrawati, N., Sangkala, I., \& Abdul, N. B. (2018). Errors in Indonesian to English Translation Text Made by Students of SMA Negeri 13 Pangkep. JKIP (Jurnal Kegururuan dan Ilmu Pendidikan), 1-17.

Fitriyani, L., \& Wennyta. (2020). An Analysis of Students' Narrative Text Translation from English to Indonesian at the Tenth Grade Students of SMA N 3 Kota Jambi Academic Year 2018/2019. JELT: Journal of English Language Teaching, 125-138.

Hadrus, M. S. (2017). The Analysis of Students Difficulties in Translating Argumentative Text from English to Indonesian. Universitas Islam Negeri Makassar.

Hastuti, Y., Kardena, A., \& Chio, E. (2020). Students' Difficulties in Translating Narrative Text from English into Indonesia at IAIN Bukittinggi. ETERNAL (English, Teaching, Learning, and Research Journal), 135-148.

Hayati, N. Y., Rusnadi, \& Rahmah, N. A. (2019). Students' Problems in Translating English into Indonesian at English Department of UIN Antasari Banjarmasin. LET: Linguistics, Literature and English Teaching Journal , 363-384.

Jumiaty, A. A. (2019). An Analysis of the Translation Products from English Text into Indonesian Language. KLASIKAL: Journal of Education Language Teaching and Science, 48-54. 
Kembaren, F. R., Muchtar, M., \& Kusumawati, T. I. (2019). Assessing English Education Department Students' Competence in Translating Indonesian Text into English. KnE Social Sciences, 247-252.

Kusumayanthi, S., \& Fitria, T. (2020). An Analysis of Translation Method Used by College Students in Translating An Article. English Journal Literacy Utama, 168-178.

Muhammad, F., Zaim, M., \& Syafei, A. F. (2018). An Analysis of Methods of Translation Used by the Third Year Student of English Department of Universitas Negeri Padang in Translating Short Narrative Text from English to Indonesian. Journal of English Language Teaching , 381-389.

Nadirah, N., Tahir, M. H., \& Asrifan, A. (2019). The Ability to Translate English Phrases into Indonesian and the Difficulties Faced by the Eleventh Grade Students of SMAN 1 Pancarijang. Journal of Advanced English Studies, 4146.

Noviyana, A., Saun, S., \& Narius, D. (2018). Students' Ability in Translating Sentences in the Recipe Text from English into Bahasa Indonesia. Journal of English Language Teaching , 354-361.

Nugraha, A., Aprianto, M., Nugroho, B., \& Rahman, Y. (2017). English-Indonesian Translating Methods in the Short Story "A Blunder" by Anton Chekhov. Indonesian EFL Journal, 79-86.

Nurhanifah, N. D., \& Haryanti, D. (2019). An Analysis Of EnglishIndonesian Translation Methods in Products' Label. Universitas Muhammadiyah Surakarta.

Permatasari, A., \& Yuliasri, I. (2020). Errors Made by Vocational School Students in Translating Analytical Exposition Text. Language Circle: Journal of Language and Literature , 191196.

Putra, A. P. (2018). An Analysis of Transposition in Translating English into Indonesian Text at The Third Semester of IAIN Metro. IAIN Metro.

Rafsanjani, A. A. (2020). Errors Analysis in Bahasa Indonesia to English Translation in Descriptive Text Made by Indonesian Students. International Conference on Science and Education and Technology (ISET 2019), 638641.

Rinaldo, V. (2020). Students' Ability in Translating Narrative Text from Indonesian into English. 7th International Conference on English Language and Teaching (ICOELT 2019), 215-219.

Rusni, R. (2018). Students' Method in Translating English Text into Indonesian Text at English Literature Department. Universitas Islam Negeri Alauddin Makassar .

Yessy, G., \& Sinambela, E. (2018). An Analysis of Students' Ability in Translating the Analytical Exposition Text in Eleventh Grade of SMK N 11 Medan. Episteme, 1. 
